\title{
Andrzej Wierciński Hermeneutyczne rozumienie W-cielenia i Eucharystii: Tenebrae Paula Celana i interpretacyjny charakter kom-unii poprzez ciało, krew i obraz
}

\begin{abstract}
Wierciński Andrzej, Hermeneutyczne rozumienie W-cielenia i Eucharystii: "Tenebrae" Paula Celana i interpretacyjny charakter kom-unii poprzez ciało, krew i obraz [Hermeneutic understanding of the Incarnation and the Eucharist: Paul Celan's Tenebrae and the interpretive nature of communion through body, blood and image]. „Przestrzenie Teorii” 21. Poznań 2014, Adam Mickiewicz University Press, pp. 299-308. ISBN 978-83-232-2740-3. ISSN 1644-6763.

Carnal hermeneutics shows that pre-thematic bodily hermeneutics can complement cognitive hermeneutics. The thematization of sacramental imagination is an essential part of such an approach. Carnal hermeneutics finds new ways of showing how imagination inhabits our bodies and reflects on the emancipatory possibilities that are hidden in the process of maintaining and crossing the various boundaries that constitute our identity. Carnal reading is both reception and creation, i.e., it is not a reading into something but a reading from something. The act of interpreting Paul Celan's Tenebrae is an exercise in a diacritical hermeneutics of communion and prayer, which contributes to the self-awakening of existence by elucidating the fundamental structures of our understanding of being.
\end{abstract}

Od początku dziejów relacja pomiędzy człowiekiem jako stworzeniem i Bogiem jako Stwórcą była bardzo intymna i cielesna, jak czytamy w Psalmie 63,11:

Boże, Ty Boże mój, Ciebie szukam;

Ciebie pragnie moja dusza,

za Tobą tęskni moje ciało,

jak ziemia zeschła, spragniona, bez wody.

W świątyni tak się wpatruję w Ciebie,

bym ujrzał Twoją potęgę i chwałę.

Skoro łaska Twoja lepsza jest od życia,

moje wargi będą Cię sławić.

Tak błogosławię Cię w moim życiu:

wzniosę ręce w imię Twoje.

Dusza moja się syci niby sadłem i tłustością,

radosnymi okrzykami warg moje usta Cię chwalą,

1 Teksty biblijne podaję w tłumaczeniu Biblii Tysiąclecia: Pismo Święte Starego $i$ Nowego Testamentu $w$ przekładzie z języków oryginalnych, wyd. 5, Poznań 2000. 


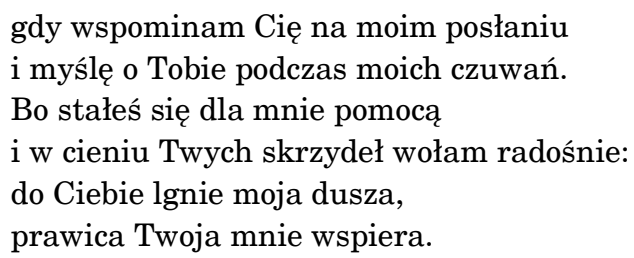

Pragnienie i tęsknota dobitnie wyrażają intymność relacji, która istnieje i rozwija się między człowiekiem a Bogiem. Tęsknota ciała jest porównana do tęsknoty duszy. Słyszymy tu wyraźnie odniesienie do Genesis, do stworzenia człowieka z prochu ziemi. Rewelacyjny opis w Genesis pokazuje, jak Bóg stworzył człowieka z ziemi; jest prawdziwym objawieniem (re-velatio) relacji między Stwórcą i stworzeniem. „Wtedy to Pan Bóg ulepił człowieka $\mathrm{z}$ prochu ziemi i tchnął w jego nozdrza tchnienie życia, wskutek czego stał się człowiek istotą żywą. A zasadziwszy ogród w Eden na wschodzie, Pan Bóg umieścił tam człowieka, którego ulepił” (Gen 2,7-8). Ciało stworzone $\mathrm{z}$ prochu ziemi tęskni za żywą wodą, za tchnieniem Boga, które ożywia proch.

W Księdze Jeremiasza 3,14 Bóg mówi: ,jestem Panem waszym”. Wyznanie to możemy rozumieć jako głos Stwórcy do człowieka, mówiący o intymnej relacji zaślubin, co w odniesieniu do Księgi Rodzaju 2,24 przypomina o deklaracji stania się jednym ciałem. Jest to szczególnie nośny wymiar, zwłaszcza w relacji do obietnicy Mesjańskiej, że „Dziewica pocznie i porodzi Syna i nadadzą mu imię Emmanuel, to znaczy: «Bóg z Nami»" (Mt 1,23, por. Iz 7,14). Jest to obietnica Boga, który zapewnia o swojej bliskości. Głos Boga, który jest bliski, jest ze swoim ludem.

W Ewangelii Jana 6,51-58 Jezus mówi o sobie jako ciele, które ma być spożywane, by mieć życie wieczne: „Jam jest chleb życia. Ojcowie wasi jedli mannę na pustyni i pomarli. To jest chleb, który z nieba zstępuje: kto go spożywa, nie umrze. Ja jestem chlebem żywym, który zstąpił z nieba. Jeśli kto spożywa ten chleb, będzie żył na wieki. Chlebem, który Ja dam, jest moje ciało za życie świata. Sprzeczali się więc między sobą Żydzi, mówiąc: «Jak On może nam dać [swoje] ciało do spożycia?» Rzekł do nich Jezus: «Zaprawdę, zaprawdę, powiadam wam: Jeżeli nie będziecie spożywali Ciała Syna Człowieczego i nie będziecie pili Krwi Jego, nie będziecie mieli życia w sobie. Kto spożywa moje Ciało i pije moją Krew, ma życie wieczne, a Ja go wskrzeszę w dniu ostatecznym. Ciało moje jest prawdziwym pokarmem, a Krew moja jest prawdziwym napojem. Kto spożywa moje Ciało i Krew moją pije, trwa we Mnie, a Ja w nim. Jak Mnie posłał żyjący Ojciec, a Ja żyję przez Ojca, tak i ten, kto Mnie spożywa, będzie żył przeze Mnie. To jest chleb, który z nieba zstąpił - nie jest on taki jak ten, który jedli wasi przodkowie, a poumierali. Kto spożywa ten chleb, będzie żył na wieki»".

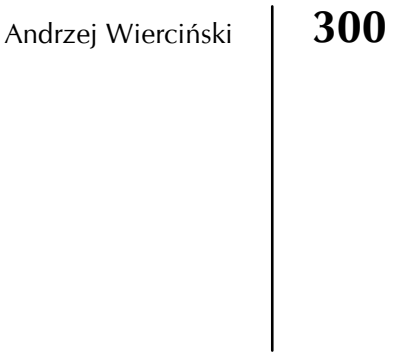


Ten fragment Ewangelii rozpoczyna się ważną formułą ego eimi

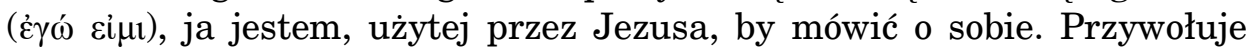
ona sposób, w jaki Bóg objawia się Mojżeszowi w Księdze Wyjścia 3,14: " JESTEM, KTÓRY JESTEM». I dodał: «Tak powiesz synom Izraela: JESTEM posłał mnie do was»". Podobnie jak Bóg Ojciec używa sformu-

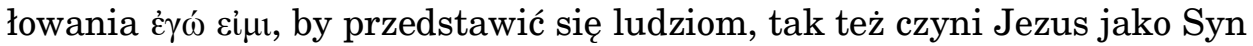
Boży. Ojciec objawia się jako ten, który jest. Syn mówi o sobie, że jest $\dot{z} y w y m$ chlebem. Jezus w-ciela się, staje się ludzkim ciałem (in carne), by być z ludźmi. Daje siebie człowiekowi, by stać się z nim jednym ciałem.

Wymowny gest pozostania ze swoim ludem w jego ciele i krwi dzieje się $\mathrm{w}$ nocy tuż przed wydaniem na ukrzyżowanie. Stwarza on nowe przymierze w ciele: od teraz każdy może uzyskać pożywienie i umocnienie w drodze. Może! To sprawa najwyższej wagi. Żeby mieć życie! Dlatego Jezus przestrzega: „Jeżeli nie będziecie spożywali mojego ciała i pili mojej krwi nie będziecie mieli życia w sobie". Przestroga ta brzmi jeszcze bardziej dramatycznie po łacinie: Nisi manducavéritis meam carnem, et bibéritis meum sánguinem, non habébitis vitam in vobis ipsis.

„To jest chleb, który z nieba zstąpił - nie jest on taki jak ten, który jedli wasi przodkowie, a poumierali. Kto spożywa ten chleb, będzie żył na wieki". W Eucharystii Jezus daje nie tyle okruchy chleba, konieczne do życia, ale pokarm na życie wieczne. Manna podtrzymywała życie Izraelitów, pielgrzymujących do Ziemi Obiecanej. Jezus, który ofiarowuje siebie człowiekowi, staje się pokarmem w pielgrzymce do życia wiecznego. Nie chodzi tu jedynie o rozumienie Eucharystii jako viaticum, czyli przyjmowanie komunii, kiedy człowiek przechodzi z życia ziemskiego do życia wiecznego. Każda komunia jest wspomożeniem w drodze pielgrzyma, jest przekroczeniem (passing-over, passio) siebie. Jest też współ-czuciem (com-passio) wobec innych, potrzebujących. To również współ-czucie, życzliwość i dobroć wobec siebie samego. Współczucie to dobroć i uważność wobec siebie i innych, otwarcie na rzeczywistość $\mathrm{z}$ „maksymalnym natężeniem uwagi" 2 . Jest to aktywne współczucie, skłaniające do twórczego poszukiwania rozumienia samego siebie, innych, świata i Boga.

\section{Eucharystia jako kom-unia}

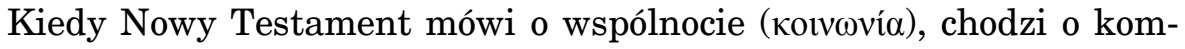
-unię intymnego uczestnictwa (intima participatio). Komunia jest unią, przymierzem między Jezusem a wspólnotą, która żyje jego obecnością.

Unikalne więzi, rozwinięte w ziemskiej zbawczej misji Jezusa osiągają nowy i głęboki poziom intymności, bezprecedensowy w historii ludzko-

2 S. Weil, The Notebooks of Simone Weil, przeł. A. Wills, New York 2004, s. 240. 
ści, w spożywaniu jego ciała i piciu jego krwi. Każdy, kto kiedykolwiek będzie to czynił, pamiętając o darze ofiarowanym przez Jezusa na Ostatniej Wieczerzy, staje się z nim jednym ciałem.

Mojżesz dał Izraelowi mannę na pustyni. Bóg wyraźnie pokazuje, że los jego ludu nie jest mu obojętny. Sam żywi swój lud i troszczy się o niego w wymiarze zarówno duchowym, jak i cielesnym. Absolutną nowością Jezusa jest to, że nie daje on jedynie czegoś, czego człowiek potrzebuje. Daje siebie samego. Jako „prawdziwy chleb z nieba” żywi swoim ciałem i krwią. Rozpoznając potrzeby człowieka, Jezus okazuje współ-czucie. Jego współ-czucie jest najgłębszą formą sympatii ( $\sigma 0 \mu \pi \alpha ́ \theta \varepsilon 1 \alpha)$, umiejętności trafnego docierania do drugiego człowieka, rozumienia jego potrzeb, empatowania jego przeżyć ( $\varepsilon \mu \pi \alpha ́ \theta \varepsilon ı$, empathy, Einfühlung). Jako w-cielony Bóg, wcielał się w rolę człowieka i poprzez empatowanie pokazywał zrozumienie dla potrzebujących, ucząc tym samym wrażliwości na potrzeby drugiego, tolerancji dla inności, kształtując postawy wzajemnej pomocy i wsparcia. Sympatia i empatia Jezusa prowadzą go ku takiej solidarności z potrzebującymi, że on sam bierze na siebie ich brzemiona, nie tylko cierpiąc z ludźmi, ale też dla ich zbawienia.

Jest coś całkowicie wyjątkowego w cielesnej komunii z Jezusem. Poprzez swoją zbawczą misję nie przemienia on automatycznie ludzkiego ciała $\mathrm{w}$ jeden organ $\mathrm{z}$ nim. Nazbyt ważny jest dla niego człowiek, by mu cokolwiek narzucać. Tym bardziej Jezus nie narzuca siebie. Zwraca się jedynie i prosi, by spożywać jego ciało i pić jego krew. Jest to znakomity dar i zaproszenie. Powołaniem człowieka jest akceptacja tego daru. Tylko wtedy, kiedy człowiek przyjmuje ciało i krew Jezusa staje się jednym ciałem z nim. Stąd też ten intymny, widzialny dar Jezusa z siebie domaga się ludzkiej odpowiedzi (Wort-Ant-wort). Odpowiedź ta jest wejściem w przestrzeń odpowiedzialności (Ver-antwortung). Dar cielesny daje siebie: A carnal gift, which gives itself. Możemy tu mowić o fundamentalnym wymiarze najbardziej pierwotnej passio essendi Eucharystii. To takie bycie danym, które chce być $\mathrm{w}$ drugim, $\mathrm{z}$ drugim (re-ceptio, re-ceived to be). Świadome uznanie boskiego daru motywuje do przyjęcia ciała i krwi Jezusa. Nigdy nic nie może się zdarzyć bez ludzkiego Amen, bez bezwarunkowego tak wypowiedzianego do tego, który chce być jednym ciałem z człowiekiem.

\section{Eucharystia - Święto Miłości i Życia}

Jezus mówi do apostołów podczas Ostatniej Wieczerzy: bierzcie i jedzcie. Przedziwne z-jedno-czenie. Nie wyklucza nikogo, nawet Judasza, choć wie, że już niebawem go zdradzi, co więcej, już zdradził go w swoim sercu. Eucharystia nie jest nagrodą za życie bez skazy! Jezus 
nie mówi o doskonałym lub niedoskonałym zjednoczeniu $\mathrm{z}$ nim. Wręcz przeciwnie, jednoznacznie zachęca wszystkich, by przyszli do niego: „Kto spożywa moje Ciało i Krew moją pije, trwa we Mnie, a Ja w nim. Jak Mnie posłał żyjący Ojciec, a Ja żyję przez Ojca, tak i ten, kto Mnie spożywa, będzie żył przeze Mnie”. Spożywanie ciała Jezusa i picie jego krwi jest jedyną gwarancją życia przez niego. Nie ma osobistej trans-formacji bez akceptacji daru eucharystycznego Jezusa. Jego, prawdziwy chleb życia, nie zdobędzie się ludzkim wysiłkiem. On przychodzi do człowieka jako cielesny dar Bożej miłości: staje się ciałem, by u kresu życia na ziemi dać swoje ciało w darze. Człowiek ma prosić o to ciało i krew i z radością je przyjmować, jeśli chce żyć wiecznie. Trudno nie zauważyć, że zaproszenie do cielesnej kom-unii nie pochodzi od człowieka. Ono zawsze przychodzi od tego, który dał swoje ciało i krew do spożywania. Możliwość usłyszenia tego zaproszenia zakłada, że istnieje już komunia między Jezusem i zaproszonym przez niego człowiekiem. W Eucharystii dokonuje się tajemnica dalszego umocnienia i udoskonalenia istniejącej już kom-unii.

Szczególnie poruszający w rozumieniu Eucharystii jest jej cielesny wymiar. Pragnienie ludzkiego serca, by jednoczyć się z Jezusem, choć jest duchowo wzbogacającym doświadczeniem, nie może zastąpić fizycznego zjednoczenia z nim. Nie ma granic dla ingerencji Boga; jego miłość może prze-mieniać człowieka w różnych wymiarach. Jednakże szczególne znaczenie $\mathrm{w}$ tym egzystencjalnie doniosłym wydarzeniu, kiedy historyczny Jezus dzieli swoje ciało i krew z uczniami podczas Ostatniej Wieczerzy, przypada cielesnemu zjednoczeniu się z nim.

Trans-formacja człowieka dokonuje się, kiedy czerpie on życie z Boga. Każda tras-formacja jest formacją. Ustanawiając Eucharystię, Jezus bierze pod uwagę realia życia jego uczniów, a więc pośrednio wszystkich ludzi. Wydaje się, że realia te nie są i nie mogą być przeszkodą dla personalnej unii cielesnej z nim. Wręcz przeciwnie, to one motywują Jezusa do zaoferowania siebie dla każdego, kto kiedykolwiek będzie spożywać jego ciało i pić jego krew. Nie ma innego sposobu, aby mieć życie (wieczne), aniżeli pozwolić sobie, by Jezus o-żywiał, by człowiek czerpał życie $\mathrm{z}$ niego.

Jest jeszcze inny, szczególnie ważny aspekt cielesnego zjednoczenia się z Jezusem. Po Ostatniej Wieczerzy możemy mówić o nowym znaczeniu kom-unii z nim w wymiarze percepcji wzrokowej. Spożywanie ciała Jezusa i picie jego krwi staje się widoczną kom-unią z nim. Nie deprecjonując roli niewidzialnej komunii z Ojcem przez Syna w Duchu Świętym, życzeniem Jezusa jest być widzialnie zjednoczonym z ludźmi. Hans-Georg Gadamer przypomina nam, że chrystologia greckich ojców Kościoła, wypracowana w duchu neoplatońskim, w decydujący sposób przyczyniła się 
do przezwyciężenia starotestamentalnej krytyki obrazów ${ }^{3}$. Widzieli oni $\mathrm{w}$ wydarzeniu Wcielenia Boga fundamentalne potwierdzenie wagi zewnętrznego wyglądu i przez to uprawomocnili dzieła sztuki. W przezwyciężeniu zakazu kultu obrazów możemy dopatrzyć się decydującego impulsu do rozwoju sztuk plastycznych na chrześcijańskim Zachodzie.

Oddajmy głos sztuce.

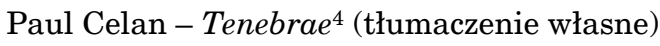

Jesteśmy blisko, Panie, blisko i osiaggalni.

Schwytani już, Panie, sczepieni ze sobą jak gdyby ciało każdego z nas było Twoim ciałem, Panie.

Módl się, Panie, modl się do nas, jesteśmy blisko.

Schyleni szliśmy pod wiatr szliśmy by się pochylić nad przepaścią.

Do źródła szliśmy, Panie.

To była krew, ta którą przelałeś, Panie.

Lśniła.

Wycisnęła w naszych oczach Twój obraz, Panie.

Usta i oczy otwarte i puste, Panie.

Piliśmy Panie.

Krew i obraz, który był we krwi, Panie.

Módl się, Panie.

Blisko jesteśmy.
Nah, sind wir Herr, nahe und greifbar.

Gegriffen schon, Herr, ineinander verkrallt, als wär der Leib eines jeden von uns dein Leib, Herr.

Bete, Herr,

Bete zu uns, wir sind nah.

Windschief gingen wir hin, gingen wir hin, uns zu bücken nach Mulde und Maar.

Zur Tränke gingen wir, Herr.

Es war Blut, es war, was du vergossen, Herr.

Es glänzte.

Es warf uns dein Bild in die Augen, Herr.

Augen und Mund stehn so offen und leer, Herr.

Wir haben getrunken, Herr.

Das Blut und das Bild, das im Blut war, Herr.

Bete, Herr.

Wir sind nah.

${ }^{3}$ H.-G. Gadamer, Truth and Method, 2nd rev. ed., trans. J. Weinsheimer, D.G. Marshall, New York 2004, s. 136: "It seems that the Greek fathers used this kind of Neoplatonic thinking in overcoming the Old Testament's hatred of images when it came to christology. They regarded the incarnation of God as a fundamental acknowledgment of the worth of visible appearance, and thus they legitimated works of art. In their overcoming the ban on images we can see the decisive event that enabled the development of the plastic arts in the Christian West".

${ }^{4}$ P. Celan, Tenebrae, [w:] tenże, Gesammelte Werke, vol. 1, ed. B. Allemann, S. Reichert, Frankfurt am Main 1983, s. 163. 
Inwersja Celana: „Módl się, Panie,/módl się do nas,/jesteśmy blisko”, wydaje się na początku tylko prostym bluźnierstwem. Szczególnie, kiedy nie godzimy się ze stwierdzeniem Theodora W. Adorna, że tworzenie poezji po Auschwitz jest barbarzyństwem („nach Auschwitz ein Gedicht zu schreiben, ist barbarisch"), inwersja Celana może być sposobem na radzenie sobie $\mathrm{z}$ doświadczeniem życia ${ }^{5}$. Jest to doświadczenie człowieka,

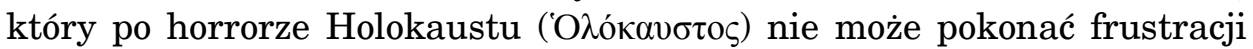
i rozpaczy i ponownie nawiązać relacji z Absolutem. To doświadczenie braku orientacji, braku kierunku. Celan, Żyd-ocaleniec z Czerniowców, który stracił w obozie koncentracyjnym rodziców i sam był więźniem rumuńskiego obozu pracy, desakralizuje przedmiot kultu (w wymiarze formalnym), szukając nowego języka bliskości z Bogiem. Jego retoryka jest retoryką fascynacji i wyobcowania, a jednocześnie podkreśla niezwykłe pragnienie Transcendencji, przy całej niezwykle skomplikowanej złożoności osobistej relacji do personalnie rozumianego Boga. Z przerażającą mocą Celan opisuje pustkę życia po dramatycznym uświadomieniu sobie, że mimo brutalności ludzi język nie zginął. Nie znajdując słów na opisanie okrucieństwa wojny, język wytrwale dźwigał ciężar historii. Wytrwa-

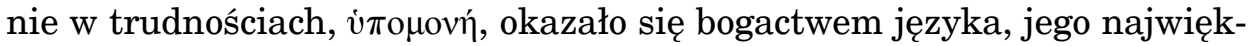

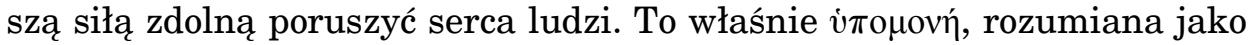
cierpliwość, wytrwałość w przeciwnościach losu, streszcza wezwanie i wyzwanie człowieka (Heraus-forderung), by został wierny swojemu powołaniu, nawet, a może szczególnie wtedy, gdy nie do końca rozumie sens zmagania o prawdę własnego serca. Doświadczenie własnej niemocy może stać się źródłem siły twórczej, (nie)zgodą na los. Według Celana „Der Tod ist ein Meister aus Deutschland" (Fuga śmierci). To ludzie zgotowali ludziom ten los, podobnie jak kiedyś zgotowali go Jezusowi. A my dzisiaj kurczowo trzymamy się siebie z różnych powodów, które też dla nas samych nie zawsze są jasne, jak kiedyś ofiary Holokaustu kurczowo trzymały się siebie w obliczu grozy i śmierci.

Za każdym razem, kiedy Celan mówi do Boga, potrzebuje głębokiego oddechu. Słowo „Pan” jest zawsze poprzedzone przecinkiem, przerwa

\footnotetext{
5 „Je totaler die Gesellschaft, um so verdinglichter auch der Geist und um so paradoxer sein Beginnen, der Verdinglichung aus eigenem sich zu entwinden. Noch das äußerste Bewußtsein vom Verhängnis droht zum Geschwätz zu entarten. Kulturkritik findet sich der letzten Stufe der Dialektik von Kultur und Barberei gegenüber: nach Auschwitz ein Gedicht zu schreiben, ist barbarisch, und das frißt auch die Erkenntnis an, die ausspricht, warum es möglich ward, heute Gedichte zu schreiben. Der absoluten Verdinglichung, die den Fortschritt des Geistes als eines ihrer Elemente voraussetzte und die ihn heute gänzlich aufzusaugen sich anschickt, ist der kritische Geist nicht gewachsen, solange er bei sich bleibt in selbstgenügsamer Kontemplation”. Th.W. Adorno, Prismen. Kulturkritik und Gesellschaft, München 1963, s. 26.
} 
w dyskursie ma umożliwić, by nieoczekiwane mogło się zdarzyć. Może daje on przez to szansę Bogu do tchnięcia w jego nozdrza życia. Inwokacja, „Panie”, przypomina doświadczenie Starego Testamentu, kiedy to wzywano imienia Pana w czasach niedoli i dziękczynienia: „O Panie, jam Twój sługa, jam Twój sługa, syn twojej służebnicy/Tyś uwolnił moje kajdany./Złożę tobie ofiarę dziękczynienia/i wezwę imienia Pana" (Psalm 115,16-17).

Wszystko po Holokauście jest zranione: ranny jest człowiek, ranne słowo i ranny jest Bóg. Jeśli istotą modlitwy jest zaistnienie w bliskości tego, w kogo się wierzy, zwłaszcza pijąc jego krew i widząc jego obraz we krwi, to bycie w obecności Boga jest sposobem objawienia się sobie. Jezus objawia się człowiekowi jako wcielone Słowo Boga, Verbum Dei; Celan wydaje się prosić Boga, aby objawił się ludziom ponownie, aby był z nami w modlitwie, ponieważ jesteśmy blisko. Modlący się Bóg może znaleźć się w naszej obecności i tym samym objawić się nam. Oczywiście inny to Bóg i inny człowiek, który zaprasza Boga, by ten modlił się do niego. Ale po Auschwitz wszystko jest inne ${ }^{6}$. Inwersja Celana jest oparta na przejściu od modlitwy rozumianej jako samoobjawienie się człowieka Bogu do samoobjawienia się Boga człowiekowi. „Módl się, Panie” to wezwanie do takiej koncentracji egzystencjalnej, która rozpoznaje porządek świata w jego drastycznym brutalnym nieporządku. „Módl się do nas” to prośba, by Bóg odsłonił przed sobą dramat stworzonego przez siebie człowieka. A warunkiem sine qua non każdej modlitwy jest bycie z (essere con).

Kondycja współczesnego człowieka to kondycja zadręczonego poprzez różne formy zniewolenia, aż do ofiary własnej krwi. Smutne, że niewiele zmienia się w historii świata. Tragiczniej nawet, historia ta powtarza się, ponieważ nie ustają ukrzyżowania. Zawsze można znaleźć powód winy:

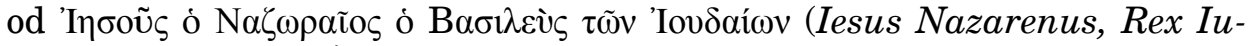
daeorum) do bycia Żydem, inaczej myślącym itp.

Mocnym akcentem są słowa Celana, kiedy pisze, że krew „wycisnęła w naszych oczach Twój obraz, Panie./Usta i oczy otwarte i puste, Panie”. Powtarzające się tragedie ukrzyżowań osłabiają wiarę w człowieka i również, przynajmniej pośrednio, w Boga, a jednocześnie niosą ze sobą szansę na inną przyszłość. Otwarte oczy i usta są niezbędne do przyjęcia daru. A pustka jeszcze dramatyczniej odsłania konieczność i pragnienie nasycenia. Wydaje się, że zarówno otwartość, jak i pustka są warunkiem moż-

${ }^{6}$ Zob. R.L. Rubinstein, After Auschwitz: Radical Theology and Contemporary Judaism, Indianapolis 1966; H. Jonas, Der Gottesbegriff nach Auschwitz: Eine jüdische Stimme, Frankfurt am Main 1987); B. Petersen, Theologie nach Auschwitz?: Jüdische und christliche Versuche einer Antwort, Berlin 1996; Als Gott weinte: Theologie nach Auschwitz, hrsg. M. Görg, M. Langer, Regensburg 1997; Christologie nach Auschwitz, hrsg. J.B. Metz, J. Manemann, Münster 2001.

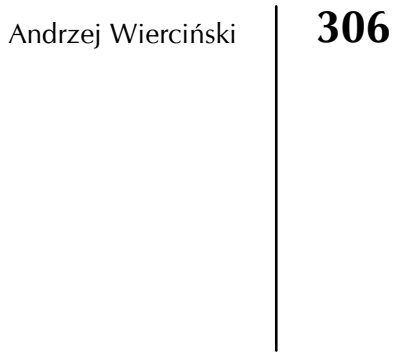


liwości wydarzenia się czegoś niesamowitego ${ }^{7}$. To właśnie „możliwość stoi wyżej od rzeczywistości”.

Nic się jednak nie zmieni w podatności na zranienie człowieka: bezwarunkowo wszystko może się zdarzyć. Modlitwa jest ofiarą niewyczerpanej energii, która może doprowadzić do kom-unii między człowiekiem i Bogiem i w ciele i krwi Jezusa. Ostateczną nadzieją ludzkości jest doświadczenie modlitwy. Kom-unia i modlitwa (kontemplacja), nie mogą być rozdzielone. Wyrażają prawdziwą troskę Boga o człowieka i człowieka o Boga.

To, co dzieje się między człowiekiem i Bogiem, kom-unia i modlitwa, domaga się rozumienia. Jest to wezwanie do dia-krytycznej hermeneutyki kom-unii i modlitwy, aby przyczynić się do samo-przebudzenia naszego istnienia przez rozjaśnienie podstawowych struktur naszego rozumienia Bycia.

\section{Konkluzja: granice wyjaśniania}

Nie ma takiego prawa ani takiej instytucji, która obejmowałaby wszystkie wymiary ludzkiego życia. Jezus jako Bóg i człowiek bezwarunkowo ofiarował swoje ciało i krew na Ostatniej Wieczerzy dla wszystkich, którzy chcą mieć życie z niego ${ }^{9}$. Wymaga to kom-unii z nim.

Jednocześnie spożywanie jego ciała i krwi kom-munię tę pogłębia i ją doskonali. Znakomita lekcja cielesnej kom-unii z Jezusem uczy, że jako istoty ludzkie nie jesteśmy $\mathrm{w}$ stanie zaspokoić naszych najgłębszych pragnień i spełnić oczekiwań i obietnic, jeśli nie zechcemy, podobnie do Jezusa, uczynić z siebie bezwarunkowego daru dla Boga i dla innych w odpowiedzi na dar nieustannie otrzymywany w kom-unii z Jezusem.

7 „So wollen wir auch Szondi zustimmen, wenn er mit dem Blick auf Celan Adornos Satz abändert: Nach Auschwitz ist kein Gedicht mehr möglich, es sei denn auf Grund von Auschwitz. Wir können seitdem vielleicht sogar noch einen Schritt weiter gehen und sagen, dass heute in Deutschland wieder unbefangene Gedichte möglich sind, weil Celan mit seinem poetischen Werk unserer Befangenheit eine Sprache gegeben hat, die brüderlich vernommen und nachgesprochen werden kann. Wir sehen darin, jenseits aller vordergründigen Ästhetik, nicht nur eine moralistische und politische Haltung, sondern den Ausdruck einer fast messianischen Stellvertretung, die nach der Katharsis dieser Gedichte, wenn man sie beklommen gelesen hat, vielleicht Unbefangenheit wieder möglich macht auf Grund von Celan". H. Weinrich, Befangenheit vor Paul Celan: Der Poet des Schweigens und die Beredsamkeit seiner Interpreten, „Die Zeit”, 23.07.1976, s. 38.

8 M. Heidegger, Sein und Zeit, Tübingen 1993, s. 38.

9 Teologicznie istotne jest rozumienie „pro multis”, „za wszystkich” albo „za wielu”, nie zapominając, że każdy przekład jest interpretacją. Por. list papieża Benedykta XVI do arcybiskupa Freiburga Roberta Zollitscha, <http://www.vatican.va/holy_father/benedict_x vi/letters/2012/documents/hf_ben-xvi_let_20120414_zollitsch_ge.html>, dostęp: 9.07.2014. 
Gadamer w słynnym rozdziale Prawdy $i$ metody, zatytułowanym „Język i Verbum", mówi o wydarzeniu Wcielenia i jego fundamentalnym znaczeniu dla zrozumienia natury języka ${ }^{10}$. Hermeneutyka Inkarnacji odkrywa najgłębszy wymiar języka i rozumienia. Rozumienie w-ciela się i jako takie jest odpowiedzią na ludzkie życie we wszystkich jego aspektach. Każde rozumienie jest aplikacją do konkretnego życia konkretnych ludzi jako dokonane (vollzogen) w ciele i krwi. Stąd też nie ma rozumienia, które nie byłoby aplikacją do życia w horyzoncie jego cielesności. Hermeneutyka cielesności, hermeneutyka ciała (carnal hermeneutics, hermeneutics of the body) są tutaj użyte w znaczeniu dopełniacza obiektywnego (genitivus objectivus), odnoszącego się do obiektu, który stanowi przedmiot interpretacji. Ciało ludzkie jest hermeneutyczne, ponieważ jest zarówno zdolne do interpretacji, jak i się jej domaga. Interpretacja ta przyczynia się do umożliwienia ciału docierania do siebie samego.

Żydzi dawnej mogli się chlubić mówiąc: „Któryż to naród wielki ma bogów tak bliskich jak Pan Bóg nasz” (Pwt 4,7). W Jezusie Bóg stał się człowiekiem. Nic, co rzeczywiście ludzkie, nie może mu być naprawdę obce. On nigdy nie będzie cudzoziemcem, nigdy foris, obcy, na zewnątrz. Ci, którzy spożywają ciało Jezusa i piją jego krew, mogą się szczerze cieszyć, że są naprawdę z nim, są błogosławionymi (bene-detti). On raczył pozostać z ludźmi aż do końca czasów. Z przebitym bokiem, z którego wypływała krew. Podobnie o Celanie można powiedzieć, za Émile'em Cioranem, że „nie był człowiekiem, ale krwawiącą raną”, „Celan war kein Mensch, sondern eine blutende Wunde".

Zarówno do mojego przekładu wiersza Celana, jak i jego odczytania można mieć wiele zastrzeżeń. Można nawet mówić o swoistym zaciemnieniu przestrzeni interpretacyjnych. Celan wielokrotnie dostrzegał zaciemnienie w swojej twórczości, rozumiejąc je jako warunek pisania, który odpowiada kondycji ludzkiej: Tenebrae, czyli ciemności. Życie człowieka to lekcje ciemności, leçons de ténèbres. Pozorne odwrócenie ról Boga i człowieka domaga się wciąż na nowo wsłuchiwania się w dialog, który toczy się od stworzenia świata. Nieustannie zmieniają się role, w których występują dramatis personae, ale zawsze chodzi o tę relację, bez której ostatecznie nie ma życia. Kiedy więc Celan wzywa Boga, by się do nas modlił, to jednak jest to wezwanie, a Psalm 145 przypomina, że „Pan jest blisko wszystkich, którzy go wzywają”. Celan ma w tym niewątpliwie całą plejadę genialnych poprzedników, od Jeremiasza i Hioba, którzy z dna egzystencjalnej rozpaczy kierowali swój lament i swoje niepogodzenie z losem do Boga.

${ }^{10}$ H.-G. Gadamer, Truth and Method, s. 418-426.

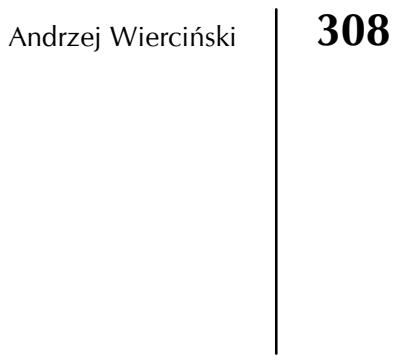

